\title{
Statyba
}

\section{PROCESSES IN CIVIL ENGINEERING MANAGEMENT}

\section{Dip.-Ing. D. Macek}

To cite this article: Dip.-Ing. D. Macek (2001) PROCESSES IN CIVIL ENGINEERING

MANAGEMENT, Statyba, 7:5, 366-369, DOI: 10.1080/13921525.2001.10531755

To link to this article: https://doi.org/10.1080/13921525.2001.10531755

Published online: 30 Jul 2012.

Submit your article to this journal $\pi$

Џ Article views: 130 


\section{PROCESSES IN CIVIL ENGINEERING MANAGEMENT}

\author{
D. Macek \\ Czech Technical University
}

\section{Introduction}

An optimisation economics of processes in the broadest sense does not express only mathematical methods for solving models with restrictive conditions, but comprises designing models and determination of restrictive conditions. It is necessary to describe all components coming into model, and to specify structures among them. Every component has a fixed position and can be included into a group with similar behaviour.

The control process means a process depending only on the decision-making. The decision-making presents a choice of concrete value in the control process. The controlled process is a process dependent on the decision-making through the control process and procedural conditions. Procedural conditions are parameters for structures among control and controlled processes. The procedural activity is a set of all control and controlled processes together with all structures procedural conditions.

A management proceeds on two levels. On the first level we choose particular processes, which will make up a model. On the second level a decision-making is realized on control processes within the model.

The first publication, which has given a systematic view on this theme, was written by V.S. Känel [1]. Afterwards virtual management moments have been defined by $\mathrm{V}$. Beran [2].

\section{Mathematical model of the problem [3]}

The control process $A[1,2]$ is a basic component of procedural activity $\mathbf{P}$, which is affected by a management on both levels. A formal notation for the procedural activity consists of $\mathrm{r}$ control processes.

$$
\mathbf{P}=\left\langle\bigcup_{i=1}^{r} A_{i}\right\rangle ; r \in N
$$

Every control process has a factual content $Q$ from which structures on controlled processes are derived.

$$
A=\langle Q\rangle \text {. }
$$

The factual content is chosen on the first level. On the second level we influent a factual content in time. Content of each control process is composed of $n$ grades, where $n \rightarrow \infty$. The factual content has a form:

$$
Q_{0}=\left\langle Q_{1}=\frac{d Q_{0}}{d t}, \ldots ., Q_{n}=\frac{d Q_{n-1}}{d t}, n \rightarrow \infty\right\rangle .
$$

An operation with singular values $Q_{i}$, where $i=1,2 \ldots . . n-1$, follows next two rules. A value change of $Q_{\mathrm{i}}$ on any grade is caused by a change on a grade $i+1$ and to keep value $Q_{\mathrm{i}}$ constant on a grade $i, Q_{i+1}$ must be equal to zero.

When choosing an appropriate grade of $Q_{n}$, we should keep an eye on a real ability to influence control process and reach relatively accurate results on this grade. In specific moments the dynamic structure is approximated to a dynamic-static model. A status between these moments is called dynamic picture. For the dynamic picture the following formula is valid:

$$
Q_{\mathrm{n}}=\text { const. if you like } d Q_{\mathrm{n}}=0 \text {, }
$$

where $n$ is a chosen grade in a control process. Further it is necessary to choose a step $d Q_{n}$, which is to be realized. Generally holds that $d Q_{n} \rightarrow 0$, but practically it is applied a value step with respect to required accuracy of results and ability to realize these values. Change $Q_{\mathfrak{n}}$ over the step $d Q_{\mathfrak{n}}$ is called a passing to another dynamic picture. These changes have a given minimal time step $d t_{\mathrm{n}}$. Such as for $d Q_{\mathrm{n}}, d t_{\mathrm{n}} \rightarrow 0$.

For grades of factual contents in control processes there is a set of limitations $\mathbf{L}$ [1,2] represents formal, organisational, technical or technological limits.

$$
\mathbf{L}=\left\langle\bigcup_{i=1}^{n}\left(l_{i}^{d} ; l_{i}^{u}\right)\right\rangle ; n \rightarrow \infty
$$


where $l^{\mathrm{d}}$ is a inferior limit and $l^{\mathrm{u}}$ is a superior limit of factual content $Q$.

The factual content (3) expands to a formula:

$$
Q_{0}=\left\{\begin{array}{l}
\left\langle Q_{1}=\frac{d Q_{0}}{d t}, \ldots ., Q_{n}=\frac{d Q_{n-1}}{d t}\right\rangle \\
n \rightarrow \infty \\
Q_{1} \geq l_{1}^{d} \wedge Q_{1} \leq l_{1}^{u} ; \\
Q_{2} \geq l_{2}^{d} \wedge Q_{2} \leq l_{2}^{u} ; \\
\ldots \ldots \ldots \ldots \ldots \ldots \\
Q_{n} \geq l_{n}^{d} \wedge Q_{n} \leq l_{n}^{u} ;
\end{array}\right\}
$$

and for control process (2) to

$$
A=\langle Q \mid \mathbf{L}\rangle \text {, }
$$

where a set of limitations $L$ can be dependent on the other control or controlled processes and also on procedural conditions.

The controlled process $B$ [2] is a further component of procedural activity that is affected directly on the first level of management and indirectly via control processes on the second level of management. The formula (1) for procedural activity with $m$ controlled processes is

$$
\mathbf{P}=\left\langle\bigcup_{i=1}^{r} A_{i}, \bigcup_{j=1}^{m} B_{j}\right\rangle ; r, m \in N .
$$

Every controlled process has a factual content $O$.

$$
B=\langle O\rangle
$$

The control process fixes a definite number of controlled processes and controlled process can be fixed by a definite number of control processes.

$$
\begin{gathered}
A \prec \bigcup_{j=1}^{y} B_{j} ; y \in N, \\
B \succ \bigcup_{j=1}^{x} A_{i} ; x \in N,
\end{gathered}
$$

where $N$ is a set of natural numbers.

Structures V [3] among control and controlled processes are direct $\mathbf{V p}$ and indirect $\mathbf{V n}$.

$$
\mathbf{v}=\left\langle\mathbf{V}_{\mathbf{p}} \times \mathbf{V}_{\mathbf{n}}\right\rangle \text {. }
$$

Direct structures express straight changing of controlled processes via control processes. Among controlled processes there are indirect structures, which can be duplex. Both structures are realized on the first grade of factual content.

$$
\begin{gathered}
O_{0}=\left\langle V_{p 1}\left(Q_{1}\right), V_{p 2}\left(Q_{2}\right), \ldots, V_{p n}\left(Q_{n}\right)\right\rangle ; n \rightarrow \infty \\
O_{0, I}=V_{n}\left(O_{0,2}\right) ; n \in N,
\end{gathered}
$$

where the second suffix means a different factual content of other controlled processes.

Next formula includes all structures on factual content controlled process.

$$
O_{0,1}=\left\{\begin{array}{l}
\prod_{i=1}^{x}\left\langle V_{p 1, i}\left(Q_{1, i}\right), V_{p 2, i}\left(Q_{2, i}\right), \ldots, V_{p n, i}\left(Q_{n, i}\right)\right\rangle ; \\
n \rightarrow \infty ; \\
\prod_{j=1}^{y}\left\langle V_{n, j}\left(O_{0, j}\right)\right\rangle ; \\
x, y \in N .
\end{array}\right\}
$$

By analogy with control processes there is a set of limitations K [2] for grades of factual content in controlled processes.

$$
\begin{gathered}
B=\langle O \mid \mathbf{K}\rangle, \\
\mathbf{K}=\left\langle\bigcup_{j=1}^{m}\left(k_{j}^{d} ; k_{j}^{u}\right)\right\rangle ; m \rightarrow \infty,
\end{gathered}
$$

where $k_{d}$ is a inferior limit and $k_{u}$ is a superior limit of factual content $O$.

Procedural conditions $\mathbf{C}[3,4]$ are parameters with changeable values, but they are constant for concrete values in both control and controlled processes. Procedural conditions are of three types. Existent $\mathbf{C}^{\mathbf{d}}-$ we can determine them, fuzzy $\mathbf{C}^{\mathbf{m}}$ - we can specify presence of probability by probability percentage and unpredictable - it is impossible to set them, but they arise during a procedural activity.

$$
\begin{gathered}
\mathbf{P}=\left\langle\bigcup_{i=1}^{r} A_{i}, \bigcup_{j=1}^{m} B_{j}, \bigcup_{k=1}^{h} \mathbf{C}_{k}\right\rangle ; r, m, h \in N, \\
\mathbf{C}=\left\langle\bigcup_{l=1}^{x} \mathbf{C}_{l}^{d}, \bigcup_{k=1}^{y} \mathbf{C}_{k}^{m}\right\rangle ; x, y \in N .
\end{gathered}
$$

The factual content of existent procedural conditions is marked $U$ and $W$ in case of fuzzy procedural conditions with a percentage probability $p$.

$$
\begin{gathered}
\mathbf{C}^{d}=\langle U\rangle, \\
\mathbf{C}^{m}=\langle p . W\rangle .
\end{gathered}
$$

An own content of procedural conditions is

$$
U_{0}=\left\langle U_{I}, U_{2}, \ldots \ldots, U_{n}\right\rangle ; n \rightarrow \infty
$$


and

$$
p_{0} . W_{O}=\left\langle p_{1} \cdot W_{1}, p_{2} \cdot W_{2}, \ldots, p_{n} . W_{n}\right\rangle ; n \rightarrow \infty .
$$

Particular grades of factual contents express two next formulas for existent and fuzzy conditions.

$$
U_{0}=\left(\begin{array}{c}
U_{1}=\frac{d U_{0}}{\prod_{i=1}^{x} d Q_{0, i} \vee \prod_{j=1}^{y} d O_{0, j} \vee d t} \\
U_{2}=\frac{d U_{l}}{\prod_{i=1}^{x} d Q_{0, i} \vee \prod_{j=1}^{y} d O_{0, j} \vee d t} \\
\ldots ., U_{n}=\frac{d U_{n-1}}{\prod_{i=1}^{x} Q_{0, i} \vee \prod_{j=1}^{y} O_{0, j} \vee d t}
\end{array}\right),
$$

where $x, y \in N$ and $n \rightarrow \infty$.

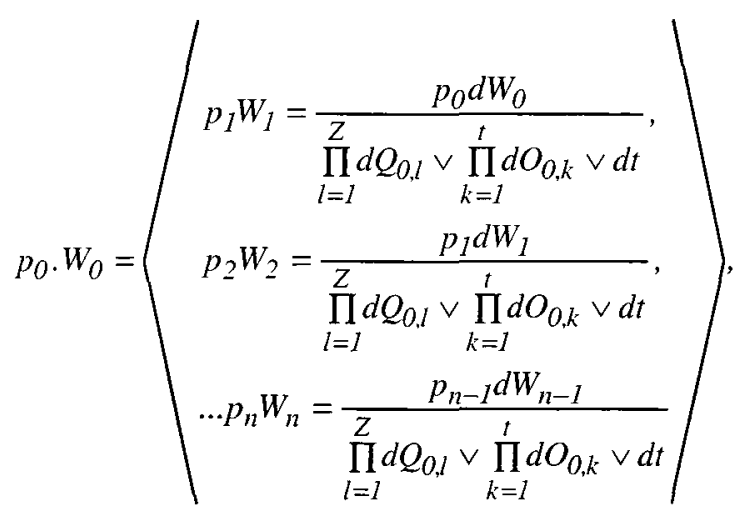

where $z, t \in N$ and $n \rightarrow \infty$.

After the conclusion of procedural conditions we get the structures formula (15) in a full version on a factual level of controlled process.

$$
O_{0,1}=\left\{\begin{array}{l}
\prod_{i=1}^{x}\left\langle\begin{array}{l}
V_{p 1, i}\left(Q_{1, i}\right), V_{p 2, i}\left(Q_{2, i}\right), V_{p n, i}\left(Q_{n, i}\right), n \rightarrow \infty
\end{array}\right\rangle ; \\
\prod_{j=1}^{y}\left\langle V_{n, j}\left(O_{0, j}\right)\right\rangle ; \\
\bar{i}\left\langle\begin{array}{l}
V_{1, k}\left(U_{1, k}\right), V_{2, k}\left(U_{2, k}\right), \\
k \ldots, V_{m, k}\left(U_{m, k}\right), m \rightarrow \infty
\end{array}\right\rangle ; \\
\prod_{l=1}^{w}\left\langle\begin{array}{l}
V_{1, l}\left(p_{1, l} W_{1, l}\right), V_{2, l}\left(p_{2, l} W_{2, l}\right), \\
\ldots ., V_{s, l}\left(p_{s, l} W_{s, l}\right), s \rightarrow \infty
\end{array}\right\rangle ; \\
x, y, z, w \in N .
\end{array}\right\}
$$

Finally, a notion of dynamic detailed picture is established. This notion specifies the dynamic picture with relations to procedural conditions. The dynamic detailed picture is a status in which all control processes and procedural conditions are constant. A mathematic formula has a form:

$$
\sum_{i=1}^{x} Q_{n, i}=\text { const. } \wedge \sum_{j=1}^{\bar{\Sigma}} U_{m, j}=\text { const. } \wedge \sum_{l=1}^{y} p_{p, l} W_{p . l}=\text { const. }
$$

where $x, y, z \in N$ and $n$ is a chosen grade on control process and $m$ and $p$ are grades on a factual content procedural conditions.

\section{Examples of model application}

The first example solves a problem of material transport from place $\mathrm{X}$ to place $\mathrm{Y}$. A goal is minimising fuel consumption. A transport sort is opted on the first level management where a concrete vehicle type is chosen. Procedural conditions are given on the same level management, which means a choice of concrete route with its technical parameters. Finally, there are expressed formulas among of all control and controlled processes and procedural conditions. The fuel consumption is a controlled process influenced by a distance change, which is a control process. A second grade of distance is chosen as a grade, where the second level management will be carried out (the first grade of distance is a velocity and the second grade is an acceleration). A direct connection to each grade of distance is expressed in a fuel consumption formula. This formula involves procedural conditions that are integrated as parameters of connection among controlled and control processes. A route vertical alignment represents existent procedural conditions and a traffic stress represents fuzzy procedural conditions. There are limitations for the first grade of distance (velocity), which are presented by the maximal speed limits on route sections. The second grade of distance (acceleration) is limited by technical potentials of a chosen vehicle. A computation of resultant formulas will be carried out by the dynamic detailed picture method with a chosen value step of acceleration on the second level management. Between changes a linear approximation of acceleration change is used. 
The second example demonstrates a problem of structural production. There is given a construction project. A goal is to minimise real building costs. Building methods, machinery and staffs are sorted out on the first level management. It is sufficient to convert different parts of construction project to common base for easier operating. The suitable common base can be represented by volume of calculation costs or percentage volume. The real building costs represent a controlled process that depends on a performed chosen common base (volume of calculation costs or percentage volume). A second grade of common base is acceptable for the second level management (the first grade of common base is a volume velocity and the second grade is a volume acceleration). It is necessary to realise that calculation costs are not equal to real building costs. An actual relation is a formula, which includes connection of real costs to each grade of a chosen common base. The existent procedural conditions are involved in the choice of concrete building methods, machinery and staffs. The fuzzy procedural conditions represent, for example, climatic conditions on a site. There are limitations on the first grade of common base (volume velocity), which are given by technological limits. Organisation potentials present limits for the second grade of common base (volume acceleration). Management provided on the second level management operates with organisation variations on the second grade of chosen common base. Potential technological changes are solved on the first level management.

Mathematical expressions of both previous examples are presented in [3] and optimising solutions are demonstrated there.

\section{Conclusions}

The ambition of this paper is to evoke discussion about an ability to control economical processes. Economic processes modelling is aimed to optimise solving tasks via control processes [5]. An optimisation does not mean only to find a concrete solution, but it comprises to give more information and recommendations for a decision-making. In [6] there have been presented examples of spreadsheet applications such as a simulation a sensitivity analysis and an optimisation [7].

\section{References}

1. V. S. Känel. Kybernetik für Ökonomen. Berlin: Die Wirtschaft, 1972. $245 \mathrm{p}$.

2. V. Beran. Automation Control Systems in Civil Engineering. Prague: SNTL/ALFA, 1985. 164 p.

3. D. Macek. Economic Processes Modelling. Prague: CTU, 1999. $70 \mathrm{p}$.

4. J. Lauber. Simulation Models. Praha, SNTL 1982. 250 p.

5. H. J. Zimmermann. Operations Research: Status Trends and Applications. Weimar; paper IKM2000, 2000.

6. V. Beran. Bauablaufplanung, Kontrolle und Risikoberechnung Darstellung einer flexiblen Vorgehensweise. Weimar: Proceedings IKM, 2000.

7. D. Macek. Simulations, Balance Sensitivity and Dye Tender Optimiser. Prague: reference manuals, 2000. 20 p.

lteikta 20010221

\section{EKONOMINIU PROCESŲ MODELIAVIMAS}

\section{Macek}

\section{Santrauka}

Ekonominių procesu optimizavimas plačiaja prasme nèra vien tik matematiniu metodu taikymas sprendimo modeliams su ribojimais, jis apima projektavimo modelius ir ribojančil sąlygų apibrèžimą. Svarbu apibūdinti visus modelio komponentus ir nurodyti ju tarpusavio priklausomybę. Kiekvieno komponento padètis yra nustatyta ir jis gali būti itrauktas i panašiai funkcionuojančią grupę.

Pateiktu modeliu demonstruojami procedūrines veiklos elementai. Procedũrinė veikla apima pačią kontrolę ir kontroliuojamus procesus, ịskaitant procedūrų sąlygas. Procedūrų sąlygos - tai parametrai, apibūdinantys priklausomybę tarp kontrolès ir kontroliuojamų procesú. Kontrolès procesas reiškia procesa, priklausanti tik nuo sprendimu prièmimo. Sprendimu prièmimas reiškia tam tikros vertès pasirinkimą kontrolès procese. Kontroliuojamas procesas priklauso nuo sprendimu prièmimo ir yra pavaldus kontrolès procesui ir procedūru sąlygons.

Valdymas vyksta dviem lygiais. Pirmuoju lygiu pasirenkami tam tikri procesai, kuriais papildomas modelis. Antruoju lygiu sprendimu prièmimas yra realizuojamas kontrolès procesais modelio viduje.

Daniel MACEK. Dip.-Ing., Assistant Professor. Dept of Construction Economics and Management. Czech Technical University, Faculty of Civil Engineering, Thakurova 7, 16629 Prague 6, Czech Republic.

Graduation: in 1999 (economics and management). Research interests: using economic models in operative management and programming computer tools for their optimisation. 